\title{
ANALYSIS OF SOLAR ENERGY POTENTIAL BY REMOTE SENSING TECHNIQUES IN VARAŽDINSKA COUNTY, CROATIA
}

\author{
Nikola Kranjčić1*, Anja Bek ${ }^{1}$, Bojan Đurin ${ }^{2}$, Suraj Kumar Singh ${ }^{3}$ and Shruti Kanga ${ }^{4}$ \\ 1 Faculty of Geotechnical Engineering, University of Zagreb, Hallerova Aleja 7, 42000 Varaždin, Croatia, \\ nikola.kranjcic@gfv.unizg.hr; anja.bek@gfv.hr; \\ 2 Department for Civil Engineering, University North, Jurja Križanića 4c, 42000 Varaždin, Croatia, bojan.durin@unin.hr \\ 3 Centre for Sustainable Development, Suresh Gyan Vihar University, Jaipur, India, suraj.kumar@mygyanvihar.com \\ 4 Centre for Climate Change and Water Research, Suresh Gyan Vihar University, Jaipur, India, shruti.kanga@ mygyanvihar.com
}

KEY WORDS: Solar energy, Remote sensing, Renewable energy, Solar panels, Varaždinska county

\begin{abstract}
:
Renewable energy becomes more and more considered as energy production due to great benefits and less environmental impact then traditional energy sources. As a part of the European Union, Croatia agreed upon certain energy efficiency goal that need to be achieved during certain period. In this paper we analyse solar energy potential in northern part of Croatia, Varaždinska county. Remotely sensed data, CORINE land cover, digital elevation model, is used to perform multicriteria analysis. There are different solar panels considered: mono-crystalline silicon panels, poly-crystalline silicon panels, amorphous silicon panels, gallium arsenide panels and cadmium tellurium panels. Based on remote sensing data estimated yearly production of electric energy from solar potential could be from $8.40 * 10^{7}$ to $2.43 * 10^{10} \mathrm{kWh}$ depending on different slope of solar panels. Gallium arsenide panels shows best usability depending on slope estimated energy production is from $2.52 * 10^{10}$ to $7.30^{*} 10^{10} \mathrm{~kW}$.
\end{abstract}

\section{INTRODUCTION}

Renewable energy is energy created from natural sources whose characteristic is that they are inexhaustible, i.e., they are constantly renewed in nature. Renewable energy technologies include solar energy, wind power, hydropower, and geothermal and biomass energy (Termorad, 2020).

Solar energy is energy that comes from the Sun - thermonuclear fusion of hydrogen takes place in the sun, and because of fusion, a large amount of energy is released which is transferred to the surface, radiates to space, and part of that energy reaches the Earth. The sun is the largest and most powerful source of energy. Solar energy can be used for heating, lighting, and cooling of houses and other buildings, generating electricity, heating water, and in various industrial processes. Most forms of renewable energy come directly or indirectly from the Sun.

The advantages of solar energy are that the conversion of solar radiation into electricity by the photovoltaic effect enables the production of renewable energy, is environmentally friendly and a reliable source of energy. It also has a wide range of applications - especially for consumers who are isolated from the grid and for consumers who care about operational reliability, lower maintenance costs, and reduced electricity bills. The intensity of solar radiation is volatile, depending on the season, meteorological conditions, and geographical location (Ekosustav, 2020; Koprivnica, 2020).

Potential of renewable energy was greatly studied throughout the years. (Myers, 2005) evaluated solar radiation models to use them in modelling and measurement for renewable energy applications. Myers concluded that all models are as good as the input data. (Wang et al., 2009) evaluated three different renewable energy models, but they did not include Croatia in their study. Surrounding countries such as Slovenia and Bosnia and Herzegovina resulted in total potential of 464 and 264 gigawatts respectively. (Calvert et al., 2013) identified knowledge-based institutional networking as a pathway through which authorities can achieve necessary resources to mobilize a geo-information infrastructure in order to gain access to renewable energy data potential. (Matejicek, 2015) used several input data such as solar energy, wind energy, biomass potential, small hydropower plants to apply multicriteria analysis for renewable energy potential. (Avtar et al., 2019) used remote sensing and GIS to access potential of renewable energy and they have included geothermal energy in their calculations. (Gašparović and Gašparović, 2019) determined optimal solar power plant locations for coastal part of Croatia.

In this paper we deal with the potential of solar energy in Varaždinska County and provide the amounts of energy that can be obtained by using different types of panels at three different panel inclinations.

\section{CROATIA SOLAR POTENTIAL}

Due to its geographical location, the Republic of Croatia (RH) has great potential in the use of solar energy, among the largest in Europe. However, despite the great solar potential, Croatia produces less than $1 \%$ of its electricity from photovoltaic systems.

Therefore, when designing solar systems, the amount of radiated solar energy must be known. Due to large differences in the radiation of solar energy in Croatia, there is a difference in the choice of type and number of collectors in the continental and coastal areas. Figure 1 shows the amounts of global solar radiation on a horizontal surface (Ekosustav, 2020; Termorad, 2020). 


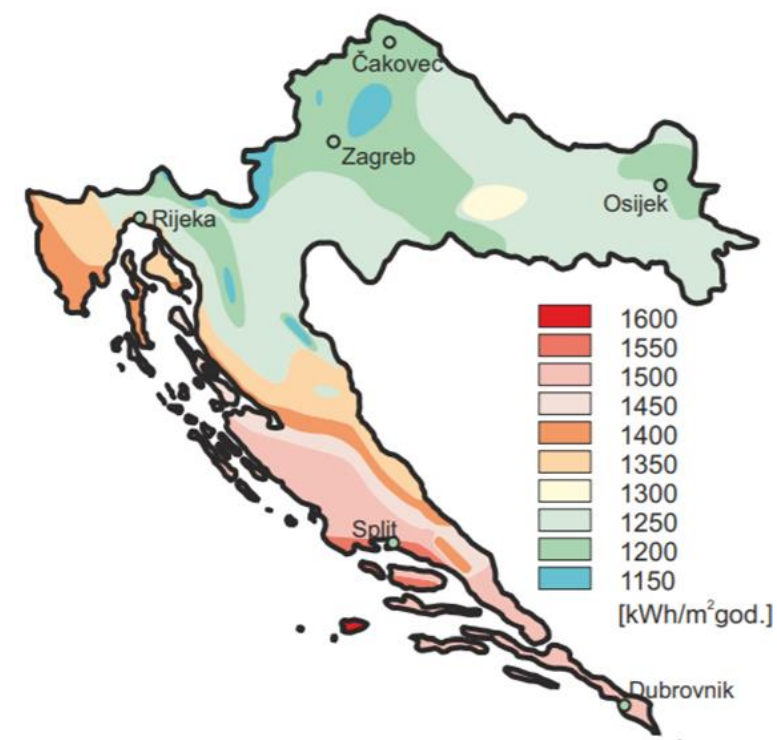

Figure 1. Mean annual amounts of global solar radiation on the horizontal surface in $\mathrm{kWh} / \mathrm{m}^{2}$ (Termorad, 2020)

\subsection{Solar technologies and principles of energy use}

Solar technologies, depending on how sunlight is collected, converted, and distributed, are described as (Koprivnica, 2020):

-

Active solar techniques - include the use of photovoltaic panels, pumps, and fans to convert sunlight into usable forms, they increase the flow of energy and are considered production technologies.

Passive solar techniques - include the selection of materials with favourable thermal properties, shaping the space in which the air circulates naturally, the orientation of buildings towards the sun, thus reducing the need for other sources and are considered consumption technologies.

The basic principles of direct use of solar energy are:

- Solar collectors - preparing hot water and heating rooms

- Photovoltaic cells - direct conversion of solar energy into electricity plants

Focusing solar energy - use in large power

The solar system consists of several components: solar panels, solar and / or storage boiler, regulation, solar pump group, expansion vessel and elements of fittings and insulated pipes. As a basic element for this conversion, photovoltaic (solar) panels are used, which are characterized by producing direct energy and need to be integrated into the photovoltaic power plant system. In doing so, the DC energy of several connected panels is converted into an alternating power system and thus delivered. Photovoltaic power plants can be the size of a part of the roof of a building, but they can also be installed on larger areas in space, and thus higher power (Koprivnica, 2020; "Photovoltaic panel," 2015; Šekelja, 2010).

A photovoltaic panel or solar panel consists of a group of solar cells (photovoltaic cells), which are usually about 36 connected in series, creating modules with a nominal voltage of $12 \mathrm{~V}$. Photovoltaic panels are semiconductor elements that directly convert solar radiation energy into electricity. Photovoltaic panels are performed in several morphological forms such as (Šekelja, 2010):
Mono-crystalline silicon panels - can convert $1000 \mathrm{Wh} / \mathrm{m}^{2}$ of solar radiation into $140 \mathrm{~W}$ of electricity, with a panel area of 1 $\mathrm{m}^{2}$.

Poly-crystalline silicon panels - can convert $1000 \mathrm{Wh} / \mathrm{m}^{2}$ of solar radiation into $130 \mathrm{~W}$ of electricity with a panel area of 1 $\mathrm{m} 2$, and the production of these panels is more economically viable.

Amorphous silicon plates - a type of plate that can convert 1000 $\mathrm{Wh} / \mathrm{m}^{2}$ of solar radiation into $50 \mathrm{~W}$ of electricity with a cell area of $1 \mathrm{~m}^{2}$, the degree of utilization of amorphous cells is much lower compared to other types of cells.

Gallium arsenide plates - this type of plate can convert $1000 \mathrm{Wh}$ $/ \mathrm{m}^{2}$ of solar radiation into $300 \mathrm{~W}$ of electricity with a cell area of $1 \mathrm{~m}^{2}$, is relatively insensitive to heat and radiation compared to silicon plates but is used in space research due to its high cost.

Cadmium tellurium CdTe panels - this type of panel can convert $1000 \mathrm{Wh} / \mathrm{m}^{2}$ of solar radiation into $160 \mathrm{~W}$ of electricity with a panel area of $1 \mathrm{~m}^{2}$ in laboratory conditions, suitable for use in thin photovoltaic modules due to physical properties and cheap manufacturing technologies, but despite these advantages due to cadmium toxicity and suspected carcinogenicity are not widely used. Electricity values are shown on an annual basis (Acumeninterior, 2020; "Photovoltaic panel," 2015).

The angle of inclination and the orientation of the panels are important for the optimal operation of the solar system. The optimal inclination of the collector for Croatia is from $30^{\circ}-45^{\circ}$, for year-round operation. Collectors can be installed from min. $15^{\circ}$ to $\max .75^{\circ}$ (Centrometal, 2020).

\section{SOLAR ENERGY POTENTIAL IN VARAŽDINSKA COUNTY}

Based on administrative borders, digital terrain model and land use and land cover for Republic of Croatia several data have been extracted. First, we calculate digital terrain model for Varaždinska county (Agency, 2020a), presented on Figure 2.

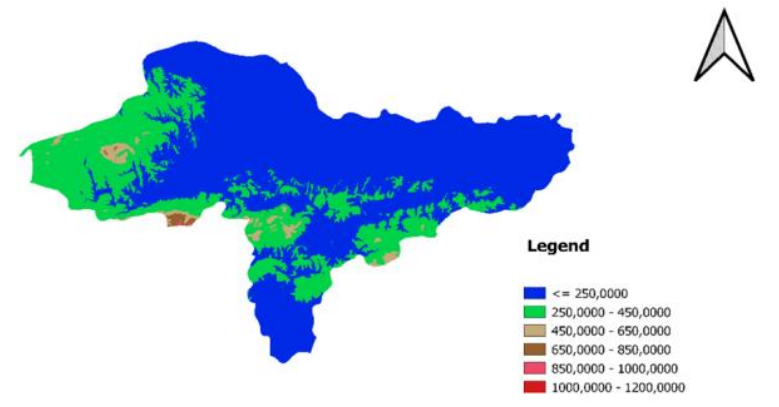

Figure 2. Varaždinska county digital terrain model

After digital terrain model creation, slope and aspect have been calculated. Figure 3 presents slope and Figure 4 presents aspect of Varaždinska county. Based on results, slope ranges from $0^{\circ}$ to $43^{\circ}$. 


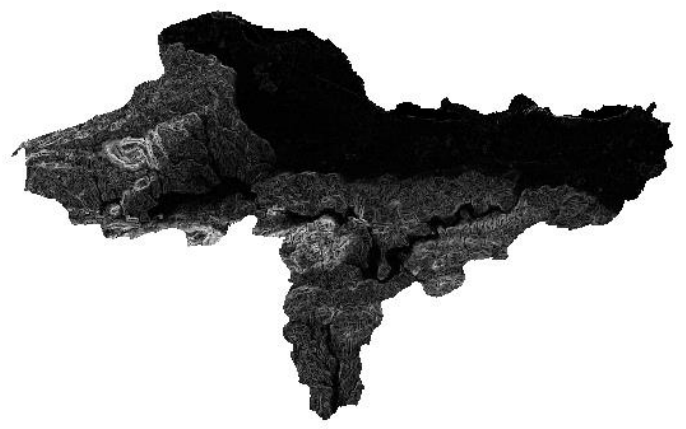

Figure 3. Varaždinska county slope model

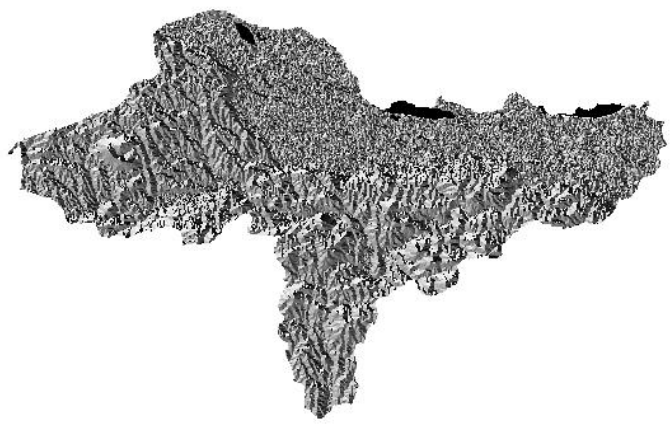

Figure 4. Varaždinska county aspect model

Based on calculations, optimal solar panel inclination for Republic of Croatia is $30^{\circ}-45^{\circ}$. Based on slope there have been areas calculated suitable for panels installation. Suitable areas are presented of Figure 5.

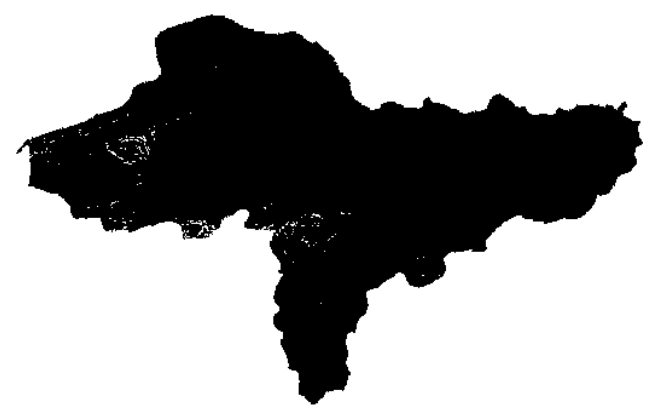

Figure 4. Suitable solar panels areas for slope $30^{\circ}-45^{\circ}$

Since the suitable areas for slope $30^{\circ}-45^{\circ}$ are relatively small, two additional slope conditions are calculated, from $27^{\circ}$ to $31^{\circ}$ (Figure 5) and from $10^{\circ}$ to $20^{\circ}$ (Figure 6), which are according to literature less effective areas, but they can be considered in preliminary calculations.

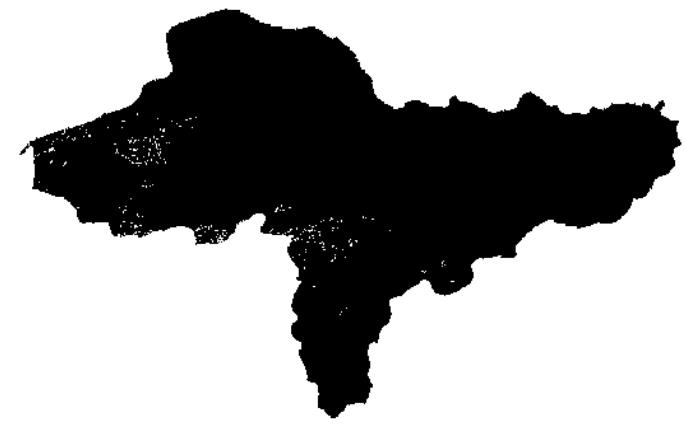

Figure 5. Suitable solar panels areas for slope $27^{\circ}-31^{\circ}$

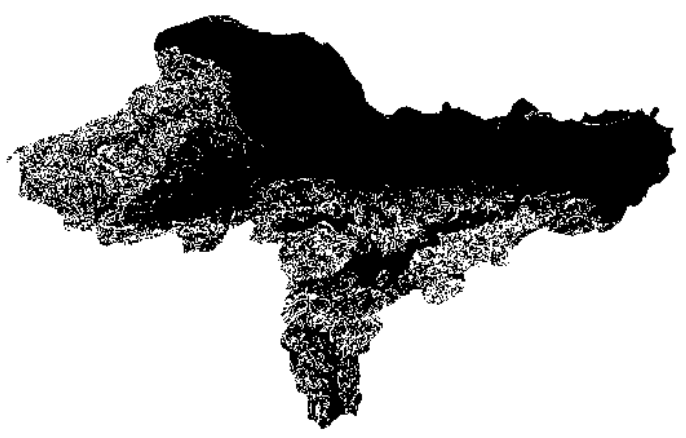

Figure 6. Suitable solar panels areas for slope $10^{\circ}-20^{\circ}$

After slopes have been defined, aspect from $180^{\circ}$ to $270^{\circ}$ is calculated because south-west side produces more solar energy.

Next, land cover is calculated since some land covers are not suitable for building solar panels. Land cover is based on CORINE land cover (Agency, 2020b). Table 1 presents land cover classification and Figure 7 presents land cover of Varaždinska county.

\begin{tabular}{|c|c|}
\hline Class & Value \\
\hline Built-up areas & $1-11$ \\
\hline Agricultural areas & $12-22$ \\
\hline $\begin{array}{c}\text { Forests and semi- } \\
\text { natural areas }\end{array}$ & $23-34$ \\
\hline Swamps & $35-39$ \\
\hline Water surfaces & $40-50$ \\
\hline
\end{tabular}

Table 1. Land cover classification 


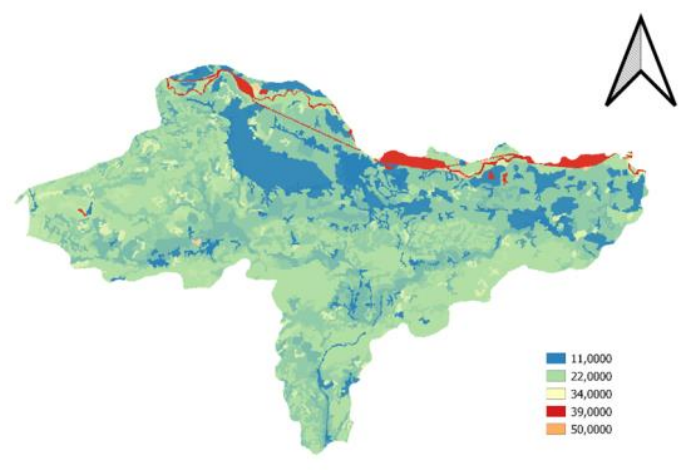

Figure 7. Land cover for Varaždinska county

Agricultural areas (values 12-22) and certain values of forests and semi-natural areas (values 26-32) such as natural grasslands, dunes, bare rocks, sparsely vegetated areas are suitable for placing panels on free areas (Figure 8). Based on CORINE land cover suitable areas were selected. White areas are suitable for building panels, and black ones are not.

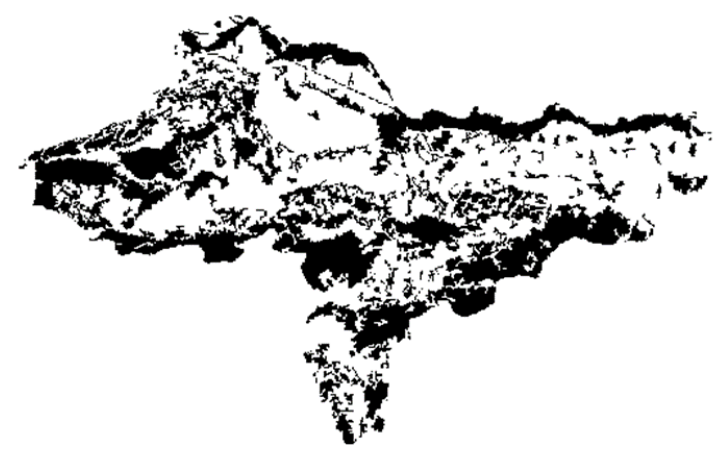

Figure 8. Land cover suitable for panels installation (white areas)

\section{RESULTS}

After slope, aspect and land cover have been combined, areas suitable for installation of solar panels are only for the slope from $10^{\circ}$ to $20^{\circ}$. Combined slope $10^{\circ}$ to $20^{\circ}$, aspect and land cover are presented of Figure 9, where white areas present suitable locations.

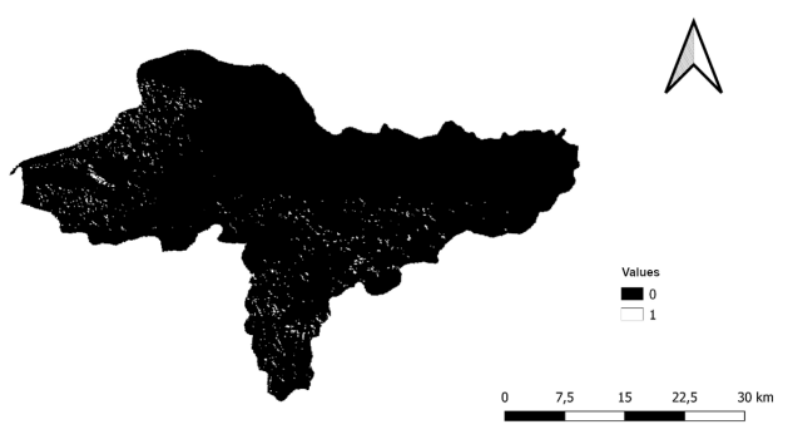

Figure 9. Suitable installation sites
Taking all calculations into account, total suitable area is 20.23 $\mathrm{km}^{2}$. If we take into consideration different solar panels, range of energy production can be calculated.

Table 2 shows potential solar energy based on different solar panels.

\begin{tabular}{|l|c|}
\hline Panels & $\begin{array}{c}\text { Energy } \\
{[\mathrm{kW}]}\end{array}$ \\
\hline Mono-crystalline silicon & $3.40^{*} 10^{12}$ \\
Poly-crystalline silicon & $3.16^{*} 10^{12}$ \\
Amorphous silicon & $1.22^{*} 10^{12}$ \\
Gallium arsenide plates & $7.30^{*} 10^{12}$ \\
Cadmium tellurium CdTe & $3.89 * 10^{12}$ \\
\hline
\end{tabular}

Table 2. Solar energy potential

Results indicate that if all available area is covered with solar panels it can range from $1.22 * 10^{12} \mathrm{~kW}$ to $7.30 * 10^{12} \mathrm{~kW}$, depending on type of solar panel installed.

\section{CONCLUSION}

After calculation of the potential amount of energy that can be obtained based on the solar potential for Varaždinska County, for the most optimal slope of the panel $30^{\circ}-45^{\circ}$ for the Republic of Croatia, and thus Varaždinska County, there are no suitable places to build panels. Therefore, the mentioned slope of the panel is unsuitable for Varaždinska County. For comparison, analysis of the surface and the amount of energy obtained for smaller inclinations of the panels $27^{\circ}-31^{\circ}$ and 10 ${ }^{\circ}-20^{\circ}$ were made. With smaller inclinations of the panels, certain areas suitable for the construction of the panels and the amount of potential energy were obtained, with the most energy being produced at the lowest inclination of the panels. According to the analysis, the slope of the panel $10^{\circ}-20^{\circ}$, with the orientation of the panel to the southwest side of the world and construction on free soil surfaces, is the most suitable slope with the greatest potential for solar electricity production in Varaždinska County and is recommended for use.

The solar panels that can convert most of the solar radiation into electricity are Gallium Arsenide Plates and Cadmium Tellurium CdTe Plates. Since Gallium arsenide plates are expensive and are used in space research, and Cadmium tellurium CdTe plates are considered toxic and carcinogenic, their use is not the most optimal. When choosing a particular type of solar panel, in addition to the amount of energy they can produce, it is necessary to consider their price, cost-effectiveness and impact on human health and the environment.

\section{REFERENCES}

Acumeninterior, 2020. Installing solar panels and most important rules of using solar panels [WWW Document]. Acumeninterior. URL https://hr.acumeninterior.com/2123513instalacja-kolektor-w-s-onecznych-i-najwa-niejsze-zasadykorzystania-z-solar-w\#menu-1 (accessed 8.13.21).

Agency, E.S., 2020a. Copernicus, Europe's eye on Earth, EUDEM [WWW Document]. URL https://land.copernicus.eu/imagery-in-situ/eu-dem/eu-dem-v1.1 (accessed 8.13.21).

Agency, E.S., 2020b. CORINE Land Cover [WWW Document]. URL https://land.copernicus.eu/paneuropean/corine-land-cover (accessed 8.13.21).

Avtar, R., Sahu, N., Aggarwal, A.K., Chakraborty, S., Kharrazi, A., Yunus, A.P., Dou, J., Kurniawan, T.A., 2019. Exploring 
Renewable Energy Resources Using Remote Sensing and https://doi.org/10.3390/resources8030149

Calvert, K., Pearce, J.M., Mabee, W.E., 2013. Toward renewable energy geo-information infrastructures: Applications of GIScience and remote sensing that build institutional capacity. Renew. Sustain. Energy Rev. 18, 416-429. https://doi.org/https://doi.org/10.1016/j.rser.2012.10.024

Centrometal, 2020. Solar systems.

Ekosustav, 2020. Sun solar energy [WWW Document]. Ekosustav. URL https://eko-sustav.hr/strucni-clanci/suncevasolarna-energija/ (accessed 8.13.21).

Gašparović, I., Gašparović, M., 2019. Determining Optimal Solar Power Plant Locations Based on Remote Sensing and GIS Methods: A Case Study from Croatia. Remote Sens. . https://doi.org/10.3390/rs11121481

Koprivnica, C., 2020. City Koprivnica - solar potential map [WWW Document]. Boost. energy Effic. Cent. Eur. cities through smart energy Manag. - Boost. URL https://kcsp.maps.arcgis.com/apps/MapJournal/index.html?appi

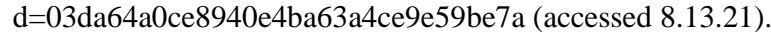

Matejicek, L., 2015. Multicriteria analysis for sources of renewable energy using data from remote sensing. Int. Arch. Photogramm. Remote Sens. Spat. Inf. Sci. - ISPRS Arch. 40, 889-896. https://doi.org/10.5194/isprsarchives-XL-7-W3-8892015

Myers, D.R., 2005. Solar radiation modeling and measurements for renewable energy applications: data and model quality. Energy 30, 1517-1531. https://doi.org/https://doi.org/10.1016/j.energy.2004.04.034

Photovoltaic panel [WWW Document], 2015. . Galaksija. URL http://www.galaksija.hr/tekst/Fotonaponska_ploca/1129 (accessed 8.13.21).

Šekelja, J., 2010. Comparing estimated and real electric energy production. University of Zagreb.

Termorad, 2020. Renewable energy sources [WWW Document]. Termorad. URL https://termorad.hr/obnovljiviizvori-energije-2/ (accessed 8.13.21).

Wang, Shifeng, Leduc, S., Wang, Sicong, Obersteiner, M., Schill, C., Koch, B., 2009. A new thinking for renewable energy model: Remote sensing-based renewable energy model. Int. J. $\begin{array}{llll}\text { Energy } & \text { Res. } & \text { 73, }\end{array}$ https://doi.org/https://doi.org/10.1002/er.1518 